Journal of Accident and Emergency Medicine 1995 12, 279-281

\title{
Non-emergency attenders at a district general hospital accident and emergency department
}

\author{
H. THOMSON, ${ }^{1}$ H.S. KOHLI² \& M. BROOKES ${ }^{3}$ \\ ${ }^{1}$ c/o Department of Public Health, University of Glasgow, Glasgow, ${ }^{2}$ Lanarkshire Health Board, \\ Hamilton, ${ }^{3}$ Monklands District General Hospital, Airdrie, UK
}

\section{SUMMARY}

Following concern about long waiting times, a survey was carried out in the Accident and Emergency (A\&E) department of Monklands District General Hospital over 5 consecutive days to investigate factors related to the bypassing of general practitioners (GPs) by 'self-referred' patients and inappropriate use of the department. Two hundred and forty-five (90.7\%) of 270 non-emergency patients who attended the department during GP surgery hours completed a self-administered questionnaire. Variables measured included recent use of health services, perceptions of the GP service and the A\&E service and reasons for bypassing the GP. Of the 245 patients, $49(20 \%)$ were defined as inappropriate and 152 (62\%) were self-referred. Self-referred patients were no more likely to use the A\&E department inappropriately than those who were referred.

Key words: non-emergency attenders, referrals, self-assessment

\section{INTRODUCTION}

The aim of the study was to describe nonemergency accident and emergency (A\&E) attenders (defined as patients who did not require the immediate attention of a medical practitioner in the A\&E department and could wait as necessary). In particular, we wished to compare those who had bypassed their general practitioner (GP)

Correspondence: Dr Harpreet S. Kohli, Consultant in Public Health Medicine, Lanarkshire Health Board, 14 Beckford Street, Hamilton ML3 OTA, UK as whether the presenting disorder could have been adequately dealt with by the GP.1,2 These criteria included the degree of illness or injury, the merit of signs and symptoms and the treatment prescribed.

\section{METHODS}

All non-emergency A\&E attenders who attended Monklands A\&E department over five consecutive weekdays during GP surgery hours (i.e. 9 am to $6 \mathrm{pm}$ ) were asked to complete a self-administered questionnaire while they were waiting to be seen. Information collected in the questionnaire included: age and sex; the perceived seriousness and urgency of the presenting disorder; recent contact with health-related services; perception of the role of the two services, i.e. the A\&E department and GP. Information on diagnosis, procedures and disposal was noted from the A\&E record.

\section{RESULTS}

A total of $\mathbf{4 4 5}$ patients attended the department during the study period. The number of nonemergency patients seen was $270(60.7 \%)$, of whom $245(90.7 \%)$ agreed to take part in the study. Of the $245,162(66.1 \%)$ were men. The mean age of the group was 28.5 years and the median was 23.5 years.

The number of patients defined as self-referred was $152(62.0 \%)$. Of these, $147(96.7 \%)$ gave the following reasons for self-referring: easier geographical access, 22 (15\%); convenience related to timing, 36 (24\%); GP's perceived inability to treat disorder, 86 (59\%); and other, four (3\%). The 152 self-referred patients form $34.2 \%$ of the total 445 patients seen in the A\&E department during the study period. 
$H$. Thomson et al. Significantly more self-referred patients $(27 \%)$ than those who had been referred $(17 \%)$ stated that their GP could have dealt with their disorders $\left(\chi^{2}, 31.76 ; P<0.0001 ; \mathrm{df}=2\right)$.

Significantly less self-referred patients $(30 \%)$ indicated they would prefer to consult their GP than those who had been referred $(61 \%)\left(\chi^{2}, 24.25\right.$; $P<0.0001$; df = 2).

Factors associated with self-referring were: 'cuts and bruises' (48\% of self-referred compared with $30 \%$ of referred patients); a perceived need to be seen within $1 \mathrm{~h}$ of deciding medical attention was necessary (73 vs. $56 \%$ ); and for those who did not self-refer, no contact with their GP for more than 6 months, other than the presenting disorder ( 49 vs. $23 \%$ ).

Of the $\mathbf{2 4 5}$ in the study, there was information on $237(96.7 \%)$ to classify them as appropriate or inappropriate attenders; 48 (20.3\%) were 'inappropriate' and 189 (79.7\%) were classified as 'appropriate'. The 48 inappropriate attenders form $10.8 \%$ of the $\mathbf{4 4 5}$ patients seen during the study period.

Table 1 shows cross-tabulation of appropriateness by procedure undertaken and inappropriate attenders were significantly less likely to need a radiograph or plaster (17 vs. $55 \%$ ).

Factors related to inappropriate attendance were: a perceived need for medical attention within 12 hours of the disorder (36 vs. 16\%); more likely to believe their GP was unable to deal with the presenting disorder (40 vs. $19 \%$ ); and more likely to have cuts or orthopaedic problems (88 vs. $61 \%$ ).

Finally, Table 2 shows that there was no significant association between self-referral and appropriateness.

\section{DIsCussion}

The results of this study support previous work which suggests that people attend the A\&E department because it is perceived as being the most appropriate place to seek medical help for the presenting disorder. ${ }^{2-4}$ In previous studies selfreferring and inappropriate use of the A\&E department have often been spoken of as related issues, ${ }^{5,6}$ but there was no evidence for this in the current study.

If it were possible to stop all the inappropriate attenders at Monklands A\&E department (who form $10 \%$ of attenders during surgery hours and about $4 \%$ of total A\&E attenders), this would mean 2500 less attenders each year. This is an average of $\mathbf{4 8}$ each week or 9.6 each weekday. However, inappropriate attenders are likely to be less seriously injured or ill than other A\&E attenders, consume less resources, be dealt with more quickly and may not significantly reduce the long waiting times sometimes experienced by patients in the A\&E department. Any measures to reduce inappropriate attendance would need to balance this with the 'safety net' aspect of seeking help at an A\&E department.

\begin{tabular}{lccc}
\hline Procedure & $\begin{array}{c}\text { Appropriate } \\
\text { No. (\%) }\end{array}$ & $\begin{array}{c}\text { Inappropriate } \\
\text { No. }(\%)\end{array}$ & $\begin{array}{c}\text { Row total } \\
\text { No. (\%) }\end{array}$ \\
\hline Radiograph/plaster & $104(55)$ & $8(17)$ & $112(47)$ \\
Appliance & $21(11)$ & $7(15)$ & $28(12)$ \\
Suture/dressing & $36(27)$ & $13(27)$ & $49(21)$ \\
Prescription & $12(6)$ & $13(27)$ & $25(11)$ \\
Other & $3(2)$ & $1(2)$ & $4(2)$ \\
None & $12(6)$ & $6(12)$ & $18(8)$ \\
Column total & $188(80)$ & $48(20)$ & $236(101)$ \\
\hline
\end{tabular}

Table 1. Cross-tabulation of appropriateness by procedure

$\chi^{\prime}, 30.97 ; P<0.0001 ;$ df $=5$.

\begin{tabular}{lccc}
\hline & $\begin{array}{c}\text { Appropriate } \\
\text { No. (\%) }\end{array}$ & $\begin{array}{c}\text { Inappropriate } \\
\text { No. (\%) }\end{array}$ & $\begin{array}{c}\text { Row total } \\
\text { No. (\%) }\end{array}$ \\
\hline $\begin{array}{l}\text { Self-referred } \\
\text { Referred }\end{array}$ & $118(62)$ & $29(60)$ & $147(62)$ \\
Column total & $71(38)$ & $19(40)$ & $90(38)$ \\
\hline
\end{tabular}

Table 2. Cross-tabulation of self-referred patients by appropriateness 
Non-emergency attenders
There is a need to quantify the cost of inappropriate use of A\&E departments, ${ }^{7}$ educate primary health care and A\&E staff so each is aware of each other's role and research the handling of emergencies by GPs to help improve A\&E services. ${ }^{8}$ Only then can the tensions in A\&E departments between providing specialist critical care and wider basic primary care begin to be resolved.

\section{ACKNOWLEDGEMENTS}

The authors thank the staff of Monklands A\&E Department for their assistance during the data collection for the study. This study was undertaken by H.T. as an MPH project in the Department of Public Health, University of Glasgow.

\section{REFERENCES}

1. Reilly P.M. (1981) Primary care and accident departments in an urban area. Journal of the Royal College of General Practitioners 31, 223-230.

2. Kljakovic M., Allan B.C. \& Reinken J. (1981) Why skip the GP and go to the A\&E department? New Zealand Medical Journal 94, 49-52.

3. Fyfe C. (1985) A study of the A\&E department, Royal Hospital for Sick Children, Glasgow; use or abuse? Unpublished MPH Dissertation, University of Glasgow.

4. Foroughi D. \& Chadwick L. (1989) A\&E abusers. The Practitioner 233, 657-659.

5. O'Flanagan P. (1976) The work of the accident \& emergency department. Journal of the Royal College of General Practitioners 26, 54-60.

6. Bradbury Y. \& Lewis B. (1991) Why do patients choose A\&E? Health and Social Service Journal Sept, 1139-1142.

7. Bliss H.A. (1982) Primary Care in the Emergency Room: High in Cost Low in Quality. New England Journal of Medicine 303, 998.

8. King's Fund (1991) Providing for Primary Care: Progress in A\&E. King's Fund, London. 